\title{
Therapeutical effect of modified adamantane copolymer compounds: Study of molecular mechanisms ${ }^{\star}$
}

\author{
Svitlana Rybalko ${ }^{1 \bowtie}$, Nadiya Nesterova ${ }^{2}$, Svitlana Diadiun ${ }^{1}$, Grygori Danylenko ${ }^{1}$, \\ Valentyna Danylenko ${ }^{1}$, Svitlana Guzhova ${ }^{1}$, Yuri Maksimov ${ }^{1}$, Viatcheslav Arkadiev ${ }^{1}$, \\ Naila Ivans'ka ${ }^{1}$, Olena Maksymenok ${ }^{1}$, Nina Vrnycianu ${ }^{1}$, Ella Zhtrebtsova ${ }^{1}$ \\ and Tanya Grygoreva ${ }^{1}$
}

\section{${ }^{1}$ Lev Gromashevski Institute of Epidemiology and Infectious Diseases, Health Ministry of Ukraine, Kyiv, Ukraine; ${ }^{2}$ Danylo Zabolotny Institute of Microbiology and Virology, National Academy of Sciences of Ukraine, Kyiv, Ukraine}

Received: 25 October, 1999; revised: 7 May, 2000; accepted: 10 January, 2001

Key words: $N$-polyvinylpyrrolidone-acrylic acid copolymers, adamantane derivatives, anti-viral therapy

\begin{abstract}
Copolymers of $N$-polyvinylpyrrolidone-acrylic acid (AB-1) and adamantane derivatives are known to possess marked antiviral activity in in vitro and in ovo models. Among the constructed preparations of AB-1 modified by adamantane derivatives some, especially AB-4 (modified by deitiforin), were found to show more extended antiviral activity and to inhibit markedly virus reproduction in susceptible permissive cell cultures and chicken embryos. In AB-4 treated cells and allantoic sacs, virus titers (influenza virus, herpes virus, and HIV) and virus antigen concentration were decreased. On the other hand, herpes virus-specific thymidine kinase and of DNA-polymerases isolated from Escherichia coli, Plectonema boryanum, and herpes virus type 1 infected murine brain tissue retained their activity after incubation with AB-4 or AB-2. The compounds investigated, in view of their effect on virus reproduction, are thought to be prospective as antiviral agents.
\end{abstract}

Copolymers of $N$-polyvinylpyrrolidone-acrylic acid (AB-1) and adamantane (AD) derivatives have been shown to possess marked antiviral activity in experiments with influenza virus [1], human immunodeficiency virus (HIV) [2] as well as with hepatitis B virus [3], rabies virus [4], and to- bacco mosaic virus [5]. Copolymers are known to act during the first step of virus reproduction, i.e. during virus adsorption to, and its fusion with the infected cell. Adamantane derivatives were found to inhibit later steps of virus multiplication, including virus particle uncoating, prevent subviral

\footnotetext{
ॠ Presented at the 7th International Symposium on Molecular Aspects of Chemotherapy, 1999, Gdańsk, Poland.

${ }^{\bowtie}$ Lev Gromashevski Institute of Epidemiology and Infectious Diseases, Health Ministry of Ukraine, Kyiv, 252038, Ukraine.

Abbreviations: AB-1, $N$-polyvinylpyrrolidone-acrylic acid; AD, adamantane; HIV, human immunodeficiency virus.
} 
particles liberation from virions, and to block the hydrophobic domain in M2-peptide of influenza virus [6].

The possibility of copolymer preparations modified by $\mathrm{AD}$ derivatives and possessing combined or new properties is of great interest. Polyanions modified by peptides and other substances show new properties; they become able to increase the immunostimulatory effect of drug preparations and to prolong their activity. Thus our aim was to study the effect of adamatane-modified copolymers on in vitro reproduction of three pathogens - influenza virus, herpes virus, and HIV - and in an attempt to understand some aspects of molecular mechanism of drug action.

\section{MATERIALS AND METHODS}

Cell cultures. Established human cell lines L41 (a lymphoid line) and MT-4 (a line of lymphoblastoid origin growing in suspension) were used in this investigation together with Vero cell line from monkey kidney tissue.

Viruses. The strain of influenza virus used was A/Hongkong/I/68/H3112/, the titers of its allantois culture were 8.0-8.5 lg egg infectious dose $\left(\mathrm{EID}_{50}\right)$, its hemagglutinin titers being 256-512 $\mathrm{HAU} / 0.2 \mathrm{ml}$.

The herpes simplex virus type 1 used, strain VC, its titers being 5.0-5.5 lg tissue culture dose $\left(\mathrm{TCLD}_{50}\right)$ in Vero cells, was received from the Dmitri Ivanovski Institute of Virology (Russian Academy of Medical Sciences, Moscow) in 1990.

The HIV-1 strain taken for our experiments was received from the Dmitri Ivanovski Institute of Virology (Russian Academy of Medical Sciences, Moscow) in 1992.

The Indiana strain of vesicular stomatitis virus (VSV) was grown in the L41 cell line, its final titers being 4.0-5.0 lg TCLD 50 .

Compounds investigated here were deitiforin, $\mathrm{AB}-1$ and its following modified derivatives: $\mathrm{AB}-2$ (modified by midantane), AB-3 (modified by remantadine), $\mathrm{AB}-4$ (modified by deitiforin), and AB-5 (modified by methyl-1-aminoethylcyclohexane) (Table 1).
The effect of the compounds studied on virus multiplication was investigated in ovo (influenza virus A/Hongkong/I/68/H3112/), in MT-4 cells (HIV) and in Vero cells (herpes virus type 1). Both chicken embryos and cell cultures were pretreated by the compound studied (see below), incubated for $30-60 \mathrm{~min}$ at $37^{\circ} \mathrm{C}$ and then infected by viruses. The titers of infectious viruses, the presence of virus specific antigens, and hemagglutinin levels were assayed in allantoic fluid (following influenza virus multiplication) or culture fluids (following HIV and herpes virus reproduction).

The infectious titer of each virus was evaluated using a series of 10-fold dilutions of virus-containing allantoic fluid or culture fluid. All dilutions of the samples taken from non-treated cultures and embryos (control samples) and of the treated ones were introduced into either chicken or into cell cultures. The embryos and the cells infected by influenza virus and herpes virus were incubated at $37^{\circ} \mathrm{C}$ during 3 days. The HIV-1-infected MT- 4 cells were kept at $37^{\circ} \mathrm{C}$ for $5-6$ days to assure HIV propagation.

Virus-specific antigens were then assayed in all samples using the hemagglutination reaction (for influenza virus) and the ELIZA approach (for herpes virus and HIV-1) [7]; to determine the p24 antigen of HIV-1, an Abbott Laboratories test-kit was used (HIV Monoclonal).

The compounds able to decrease virus infectious titers at least by $2 \mathrm{lg}$ during a single cycle of virus reproduction are thought to be prospectively active ones.

The acute toxicity of compounds investigated was assayed in mice as a model following intraperitoneal injection of the preparations used [8].

\section{Determination of DNA-polymerase activity}

in vitro was carried out according to [9] using three DNA-polymerase preparations: from Escherichia coli, Plectonema boryanum and murine brain tissue infected by the herpes virus type 1 (see below). The mixture for the in vitro DNA synthesis contained a preparation of the activated thymus DNA (Sigma), non-labeled dNTPs, and ${ }^{3}$ H-labeled dNTPs as well as ${ }^{32}$ P-labeled ATP ("Isotope", Tashkent, Uzbekistan). An enzyme activity unit 
(AU) is that quantity of the enzyme which catalyzes the incorporation of 1 nmole of the precursor into the reaction product. The total activity (TPA) of a preparation was calculated according to the equation

$$
\mathrm{TPA}=\mathrm{A} \cdot \mathrm{K} \cdot \mathrm{k},
$$

where $\mathrm{A}$ is the label found in the sample measured (c.p.m. $\cdot 1000), \mathrm{K}$ is the total volume $(\mathrm{ml})$, and $\mathrm{k}$ is the coefficient of the corresponding molar activity of the label used (0.0008-0.0016).

Each of the compounds tested $(1-100 \mu \mathrm{g} / \mathrm{ml})$ was introduced into the in vitro DNA synthesis system.

DNA-polymerase isolation from the herpes virus infected murine brain tissue [10]. The enzyme was isolated using several well-known approaches - DEAE-cellulose, phosphocellulose, and blue cellulose column chromatography as well as gel filtration through Sephadex G-150 and Sephadex G-200 columns. The yields of DNA-polymerases $\alpha, \beta$ and $\gamma$ were $2.5 \%, 4.5 \%$, and $4.5 \%$, respectively, their specific activities (per $1 \mathrm{mg}$ of protein) being $10^{5}, 11^{3}$, and $57^{4} \mathrm{AU}$, respectively.

Virus-specific thymidine kinase activity [11] of herpes virus infected cultures treated and non-treated with the compounds investigated was determined using the reaction mixture containing the enzyme, $\left[{ }^{14} \mathrm{C}\right]$ thymidine, ATP, $\mathrm{MgCl}_{2}$, dithiothreitol and Tris/ $\mathrm{HCl}, \mathrm{pH}$ 8.0. All samples were incubated at $37^{\circ} \mathrm{C}$. Each sample was then placed on two separating DEAE-filters the first was extracted twice with ethanol, the second was untreated. The two filters were dried and tested in a liquid scintillation counter Beckman LC-8000. The percentage of the $\left[{ }^{14} \mathrm{C}\right]$ thymidine converted by the enzyme was calculated according to the formula: $\mathrm{C}_{t} /\left(\mathrm{C}_{\mathrm{n}}+100\right)$, where $\mathrm{C}_{\mathrm{t}}$ is the label (c.p.m.) incorporated on ethanol-treated filters and $\mathrm{C}_{n}$ is the label (c.p.m.) incorporated on non-treated filters.

Calculations of the thymidine phosphorylated $(\mathrm{mmol} / \mathrm{h})$ were made taking into consideration the original quantity of the nucleoside monophosphate present in the reaction mixture.

Interferon-stimulating properties of modified compounds were evaluated according to their ability to induce endogenous interferon, the inter- feron titers being determined by a well-known approach using the inhibition by interferon of the vesicular stomatitis virus production in L41 cells.

Syntheses. The synthesis of $N$-vinylpyrrolidone-acrylic acid copolymers was carried out in the medium of ethanol, toluene, chlorobenzene or tetrahydrofurane. To initiate this reaction, peroxide derivatives of benzoyl or dinitrylazo-di-isobutyric acid were used, at molar ratios ( $N$-vinylpyrrolidone: acrylic acid) of $1: 1$ or $1: 2$ [12-14]. No data concerning relative molecular mass of the new polymers were mentioned in the papers cited. We have found the relative molecular mass of the copolymer synthesized in n-butanol to be below 90000 and its $N$-vinylpyrrolidon-acrylic acid ratios, 1.65-1.70. The copolymer obtained is water-soluble.

The modifications of this copolymer by amines are more effective with 2-(1-aminoethyl)norbornane compared to 1-(1-amino)- and 1-(1-aminoethyl)adamantane. We think that this might be due to the size of a carbohydrate residue.

A band at $1750 \mathrm{~cm}^{-1}$ (CO in $\left.\mathrm{COOH}\right)$ is present in the ultra-red spectrum of the original polymer; its modifications cause the appearance of new bands at $2930-2970 \mathrm{~cm}^{-1}\left(\mathrm{NH}_{3}{ }^{+}\right)$and at 1570 $\mathrm{cm}^{-1}\left(\mathrm{COO}^{-}\right)$.

Preparation of the copolymer of $\mathrm{N}$-vinylpyrrolidone-acrylic acid. The mixture containing acrylic acid (7.2 g, $0.1 \mathrm{M}), N$-vinylpyrrolidone (11.1 g, $0.1 \mathrm{M})$, dinitril of azo-di-isobutyric acid $(0.2 \mathrm{~g})$, and $\mathrm{n}$-butanol was heated stepwise up to $70^{\circ} \mathrm{C}$ and stirred during $2 \mathrm{~h}$ at this temperature. Then the mixture was cooled and decanted, and the pellet dissolved in ethanol $(200 \mathrm{ml})$; this solution was then added (with stirring) to acetone $(600 \mathrm{ml})$. The yield of the product was usually $12.4 \mathrm{~g}(67 \%)$.

General approach used for copolymer modification. The copolymer obtained as described above ( $3 \mathrm{~g}$ ) was suspended in absolute ethanol (30 $\mathrm{ml}$ ). A $20 \%$ ethanol solution of a corresponding amine was added with stirring in portions of $1 \mathrm{ml}$ until the $\mathrm{pH}$ became alkalic. This mixture was then added to acetone $(300 \mathrm{ml})$ with stirring; the precipitate was separated and resuspended from ethanol into acetone. 


\section{RESULTS AND DISCUSSION}

The amine content in our modified copolymers was determined from the nitrogen content and acid number, and their relative molecular masses from the viscosity data (in dimethylsulfoxide). The data obtained are given in Table 1. compounds were made in an in ovo model of influenza infection. Solutions (0.1 ml) containing 100 $\mu \mathrm{g}$ of deitiforin, AB-1, AB-2, AB-3, AB- 4 or AB- 5 were injected into chicken embryo allantoic sac. After $1 \mathrm{~h}$ all these embryos were infected by the influenza virus (100 $\mathrm{EID}_{50}$ per embryo). Both hemagglutinin titer and infectious virus titer were

Table 1. Some properties of synthesized copolymers with general formula

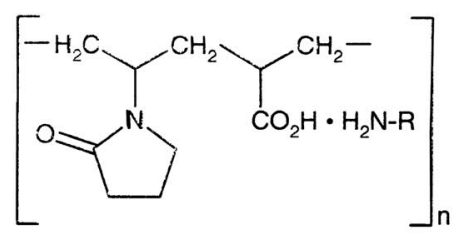

\begin{tabular}{|c|c|c|c|c|}
\hline \multirow{2}{*}{ Substance } & \multirow{2}{*}{ Yield, \% } & \multicolumn{2}{|c|}{ Content of amine according to: } & $-M 1000$ (from to) \\
\hline & & content of $\mathrm{N}$ & acid number & ${ }^{21} \mathrm{r} 1000(110 \mathrm{~min} \ldots$ lo \\
\hline AB-1 & 67 & - & - & $15-90$ \\
\hline AB-2 & 76 & 10.8 & 10.1 & $15-90$ \\
\hline AB-3 & 82 & 14.6 & 14.2 & $20-95$ \\
\hline AB-4 & 63 & 19.8 & 20.4 & $25-125$ \\
\hline AB-5 & 67 & 52.4 & 50.7 & \\
\hline
\end{tabular}

A study of acute toxicity of the preparations obtained showed (Table 2) that the $\mathrm{LD}_{50}$ values of evaluated using the allantois fluid $48 \mathrm{~h}$ post infection, the levels of virus infectivity (Table 3) being

Table 2. Acute toxicity of $N$-polyvinylpyrrolidone-acrylic acid (AB-1) copolymer modified by adamantane derivatives

\begin{tabular}{ll}
\hline Compound investigated (modification) & $\mathrm{LD}_{50}, \mathrm{mg} / \mathrm{kg}$ \\
\hline AB-1 (-) & $>3000.0$ \\
AB-2 (midantone) & 1180.0 \\
AB-3 (remantidine) & 3000.0 \\
AB-4 (deitiforin) & 3000.0 \\
AB-5 (methyl-1-aminoethylcyclohexane) & 3000.0 \\
\hline
\end{tabular}

the compounds investigated varied from 1.18 up to $3.0 \mathrm{~g} / \mathrm{kg}$; so these compounds belong to the class of moderate toxicity drugs.

Some experiments concerning the antiviral effect of several adamantane-modified copolymer determined following its titration on chorioallantois membranes.

According to our data, compounds AB-2 and AB- 4 had the most marked inhibitory antiviral effect against the influenza virus strain used. A sim- 
Table 3. Effect of some adamantane-modified copolymer compounds on the influenza virus reproduction in ovo

\begin{tabular}{lccc}
\hline Compound investigated & $\begin{array}{c}\text { Dose } \\
(\mu \mathrm{g} / \text { chicken embryo })\end{array}$ & Hemagglutinin titer & $\begin{array}{c}\text { Inhibition of infectious titer, } \\
\text { lg EID }\end{array}$ \\
\hline AB-1 & 100 & $1: 20$ & 2.0 \\
AB-2 & 100 & $1: 10$ & 3.0 \\
AB-3 & 100 & $1: 320$ & 1.0 \\
AB-4 & 100 & $1: 20$ & 3.0 \\
AB-5 & 100 & $1: 20$ & 0 \\
Deitiforin & 100 & $1: 40$ & 2.5 \\
\hline
\end{tabular}

ilar effect was also found with the herpes virus type 1 propagated in the Vero cell line (Table 4). Our experiments prove that the compounds AB-2 and $\mathrm{AB}-4$ decrease significantly the herpes virus reproduction in the in vitro model system.

The investigation of anti-HIV activity of the same compounds was also carried out in vitro. Lymphoblastoid MT-4 cells were pretreated by drug preparations (10 $\mu \mathrm{g} /$ tube), kept for $30 \mathrm{~min}$ at $37^{\circ} \mathrm{C}$ and then infected by HIV preparation
(100 $\mathrm{ID}_{50}$ /tube). All samples, both pretreated and control, were incubated at $37^{\circ} \mathrm{C}$ during 5-6 days before evaluation of their infectivity level and p24 HIV-specific antigen (Table 5). It was found that compounds AB-1, AB-2, and AB-4 inhibit HIV-1 reproduction in MT-4 cell suspensions by 2.0-2.5 lg $\mathrm{ID}_{50}$. It should be noted that the original copolymer preparation inhibited the influenza virus reproduction and its adamantane derivatives both retained this ability and aquired new properties.

Table 4. Effect of some adamantane-modified copolymer compounds on the herpes virus type 1 reproduction in Vero cell culture

\begin{tabular}{lcc}
\hline Compound investigated & Dose $(\mu \mathrm{g} /$ tube $)$ & Inhibition of infectious titer, $\lg \mathrm{ID}_{50}$ \\
\hline AB-1 & 50.0 & 1.0 \\
AB-2 & 50.0 & 4.0 \\
AB-3 & 50.0 & 2.0 \\
AB-4 & 50.0 & 6.0 \\
AB-5 & 50.0 & 1.0 \\
\hline
\end{tabular}

Table 5. Effect of some adamantane-modified copolymer compounds on HIV reproduction in in vitro infected MT-4 cells

\begin{tabular}{lcccc}
\hline $\begin{array}{l}\text { Compound } \\
\text { investigated }\end{array}$ & $\begin{array}{c}\text { Dose } \\
(\mu \mathrm{g} / \text { tube })\end{array}$ & $\begin{array}{c}\text { Titer of the p24 } \\
\text { antigen expression }\end{array}$ & $\begin{array}{c}\text { Infectious titer, } \\
\lg \text { ID }_{50}\end{array}$ & $\begin{array}{c}\text { Inhibition of infectious } \\
\text { titer, lg } \text { ID }_{50}\end{array}$ \\
\hline AB-1 & 10.0 & $1: 200$ & 2.0 & 2.5 \\
AB-2 & 10.0 & $1: 800$ & 2.5 & 2.0 \\
AB-3 & 10.0 & $1: 3200$ & 4.5 & 0 \\
AB-4 & 10.0 & $1: 200$ & 2.0 & 2.5 \\
AB-5 & 10.0 & $1: 3200$ & 5.0 & 0.5 \\
Deitiforin & 10.0 & $1: 3200$ & 3.0 & 1.5 \\
$\begin{array}{l}\text { No compound added } \\
\text { to HIV-infected cells }\end{array}$ & & $1: 3200$ & 4.5 & 0 \\
\hline
\end{tabular}


Table 6. Interferon-inducing activity of some adamantane-modified copolymer compounds compared to the effect of other drugs

\begin{tabular}{lcc}
\hline \multirow{2}{*}{ Compound investigated } & Level of interferon induction, I.U./ml \\
\cline { 2 - 3 } & $\mathrm{pH} 7.3$ & $\mathrm{pH} 2.0$ \\
\hline AB-1 & 320 & 320 \\
AB-2 & 320 & $0-40$ \\
AB-3 & 640 & 0 \\
AB-4 & 640 & $0-40$ \\
AB-5 & 640 & 0 \\
PolyI:C & 1280 & 1280 \\
Deitiforin & 160 & 160 \\
Remantadine & 160 & 160 \\
Acyclovir & 320 & 160 \\
Control & $<40$ & $<40$ \\
\hline
\end{tabular}

Thus the modifications allow to construct new substances able to inhibit also other viruses containing both DNA and RNA (herpes type 1 virus and HIV). Such universal virus inhibitors are known to be usually interferon inducers and to inhibit some virus-specific enzymes participating in virus multiplication; so the next step of our work was aimed at finding whether some modified preparations obtained possessed interferon-inducing properties, and whether they inhibited two key enzymes responsible for virus structure synthesis: DNA-polymerase and thymidine kinase.

The interferon-inducing activity of the modified preparations (AB-1, AB-2, AB-3, AB-4, AB-5) was investigated in vitro using donor blood (Table 6). It is clear that all the modified compounds studied possess the interferon-inducing activity which is higher in comparison to that of well-known popular drugs (remantadine, acyclovir); thus, without any doubt such substances deserve attention from the chemotherapeutical point of view.

To study the effect of deitiforin, AB-1 and AB-4 on the activity of thymidine kinase, two enzyme preparations were used: a standard one and a virus specific thymidine kinase preparation isolated from herpes virus type I infected cells. The data in Table 7 prove that AB- 1 inhibits neither the standard enzyme activity nor the activity of the herpes virus specific one. The inhibition of enzyme activity by deitiforin is very low (about 10-20\%). However, the AB-4 compound, i.e. a deitiforin-modified copolymer, has a higher inhibitory effect,

Table 7. Effect of some compounds studied on herpes virus specific thymidine kinase activity in vitro

\begin{tabular}{|c|c|c|c|c|c|c|}
\hline \multirow{2}{*}{$\begin{array}{l}\text { Compound } \\
\text { studied }\end{array}$} & \multirow{2}{*}{$\begin{array}{l}\text { Enzyme } \\
\text { preparations* }\end{array}$} & \multicolumn{5}{|c|}{$\begin{array}{l}\text { Residual enzyme activity (\%) at the concentrations of compounds }(\mu \mathrm{g} / \mathrm{ml}) \\
\text { studied: }\end{array}$} \\
\hline & & 1 & 5 & 10 & 20 & 40 \\
\hline \multirow[t]{2}{*}{ AB-1 } & Control & 100 & 100 & 100 & 100 & 100 \\
\hline & Infected & 100 & 100 & 100 & 100 & 100 \\
\hline \multirow[t]{2}{*}{ AB-4 } & Control & 80 & 61 & 47 & 20 & 7 \\
\hline & Infected & 84 & 70 & 36 & 20 & 10 \\
\hline \multirow[t]{2}{*}{ Deitiforin } & Control & 90 & 80 & 92 & 95 & 95 \\
\hline & Infected & 80 & 70 & 75 & 95 & 100 \\
\hline
\end{tabular}

${ }^{*}$ Control, standard thymidine kinase preparation. Infected, enzyme preparation isolated from herpes virus type I infected cells. 
Table 8. Effect of AB-1, AB-4 and deitiforin on the activity of DNA-polymerase preparations isolated from $E$. coli and $P$. boryanum

\begin{tabular}{|c|c|c|c|c|c|c|}
\hline \multirow{2}{*}{$\begin{array}{l}\text { Compounds } \\
\text { studied }\end{array}$} & \multirow{2}{*}{$\begin{array}{l}\text { Enzyme } \\
\text { preparations }\end{array}$} & \multicolumn{5}{|c|}{$\begin{array}{l}\text { Residual enzyme activity (\%) at the concentrations of compounds }(\mu \mathrm{g} / \mathrm{ml}) \\
\text { studied: }\end{array}$} \\
\hline & & 1 & 5 & 10 & 50 & 100 \\
\hline \multirow[t]{2}{*}{ AB-1 } & E. coli & 100 & 100 & 100 & 100 & 100 \\
\hline & P. boryanum & 100 & 100 & 100 & 100 & 100 \\
\hline \multirow[t]{2}{*}{ AB-4 } & E. coli & 98 & 70 & 30 & 20 & 20 \\
\hline & P. boryanum & 80 & 50 & 10 & 5 & 5 \\
\hline \multirow[t]{2}{*}{ Deitiforin } & E. coli & 60 & 30 & 40 & 40 & 35 \\
\hline & P. boryanum & 100 & 100 & 80 & 100 & 100 \\
\hline
\end{tabular}

decreasing the standard enzyme preparation activity by 80 and $93 \%$ at concentrations of 20 and $40 \mu \mathrm{g} / \mathrm{ml}$, respectively. With the same AB-4 concentrations the activity of the herpes virus specific thymidine kinase became lower by 80 and $90 \%$, respectively.

The effect of some modified compounds on the activity of DNA-polymerases from different organisms was studied using enzyme preparations isolated from $E$. coli, $P$. boryanum and herpes vi- ever, such activity of the E.coli enzyme. At the same time a deitiforin-modified compound, AB-4, inhibits markedly the $P$. boryanum DNA-polymerase.

DNA-polymerase preparations used were isolated from E. coli (I) and P. boryanum (II). According to the current DNA-polymerase classification, there are two DNA-polymerase superfamilies differing in their principal properties: a superfamily of enzymes similar to DNA-polymerase $\alpha$ of verte-

Table 9. Effect of some modified compounds on the DNA-polymerase activity of the preparation isolated from herpes virus infected murine brain cells

\begin{tabular}{|c|c|c|c|c|c|}
\hline \multirow{2}{*}{$\begin{array}{l}\text { Compounds } \\
\text { studied }\end{array}$} & \multicolumn{5}{|c|}{ Residual enzyme activity (\%) at the concentrations of compounds $(\mu \mathrm{g} / \mathrm{ml})$ studied: } \\
\hline & 1 & 5 & 10 & 50 & 100 \\
\hline AB-1 & 100 & 98 & 95 & 100 & 98 \\
\hline AB-2 & 97 & $62^{*}$ & $55^{*}$ & $55^{*}$ & $44^{*}$ \\
\hline AB-3 & 95 & $62^{*}$ & $58^{*}$ & $67^{*}$ & $44^{*}$ \\
\hline AB-4 & 80 & $45^{*}$ & $10^{*}$ & $7^{*}$ & $7^{*}$ \\
\hline AB-5 & 91 & $75^{*}$ & $47^{*}$ & $36^{*}$ & $23^{*}$ \\
\hline Deitiforin & 100 & 85 & 100 & 100 & 100 \\
\hline
\end{tabular}

${ }^{*} P<0.05$.

rus infected murine brain cells. The reaction mixtures contained increasing doses of compounds studied or deitiforin. The principal results of this investigation are given in Tables 8 and 9 . It is clear from the Table 8 the AB- 1 preparation does not affect bacterial oralgal DNA-polymerase activities. Deitiforin, which does not inhibit the $P$. boryanum DNA-polymerase activity inhibits, how- brate animals, and a superfamily of enzymes resembling the $E$. coli DNA-polymerase. DNA-polymerase preparations isolated from $P$. boryanum contain both types of enzyme, its DNA-polymerase I being of the first type and its DNA-polymerase II belonging to the second. The $P$. boryanum DNA-polymerase $\mathrm{I}$ is a repair enzyme, and its DNA-polymerase II is a cellular replicase- 
type enzyme. The comparative analysis of DNA-polymerase inhibition by AB-1, AB-4, and deitiforin revealed the following patterns. On modification by deitiforin, the resulting $\mathrm{AB}-4$ compound became able to inhibit both activities (I and II) of the enzyme preparation of $P$. boryanum origin, whereas deitiforin itself inhibited only the repair enzyme activity (II), and AB-1 showed no activity towards either type of DNA-polymerase (not shown).

The effect of some modified compounds on the virus-specific DNA-polymerase activity of murine brain cells infected by the herpes virus type 1 is shown in Table 9. The enzyme activity was also sensitive to some modified compounds (AB-2, AB-3, AB-4, AB-5), an effect proving the essential identity of the mechanism of action of virus-specific and cell-specific enzymes encoded by the host genome. Thus, the use of many antiviral compounds is limited by such identity [15]. At the same time, acyclovir is known to compete with dGTP and terminate the herpes virus DNA chain synthesis more markedly than the synthesis of the host cell DNA [16]. Therefore our compounds AB-1, AB-2, AB-3, and AB-4 are of some interest. It should be noted that neither the copolymer AB-1 nor affect the DNA-polymerase isolated from the herpes virus type 1 infected murine brain. However, the modified structure, AB-4, inhibits significantly this enzyme and, simultaneously herpes virus multiplication; another compound, AB-2, is less active with regard to virus suppression.

Cellular replicative activities are thought to be included into a hypothetical zymogen complex which can be cleaved directly or indirectly by different substances. The modified amantadine compounds might affect the conformation of enzyme-containing complexes causing the inhibition of their activities. The increased sensitivity of such complexes in virus infected cells could be also due to some modifications of the DNA-polymerase active center. The last hypothesis needs further confirmation.

We are going to continue our investigations concerning the most prospective substances among the compounds already studied.

\section{R E F E R E N C E S}

1. Dzeguse, A. (1991) Anti-influenza effect of amantadine and some of its derivatives; in New Approaches in Viral Infection Chemotherapy; p. 53-54, Riga:"Zinatne" (in Russian).

2. DeClerq, E. (1989) New approaches in the development of anti-HIV agents. Antiviral Res. 12, 1-20.

3. Prichard, W.W. (1967) Amine derivatives of 4,7-hexahydroindan. Pat. USA 3317387. Chem. Abstr. 67, N 73249.

4. Danilenko, G.I., Shablovskaya, Ye.A., Antonova, L.A., et al. (1998) Phenyladamantane derivatives as rabies virus inhibitors. Chimiko-farmaceutitcheski Zhurnal 32, 28-30 (in Russian).

5. Goonewerdene, H.F. (1968) Inhibition of the growth of plant viruses. Pat. USA 3341402. Chem. Abstr. 68, N 2266.

6. Kolocouris, N., Kolocouris, A. \& Foscolas, J.F. (1996) Synthesis and antiviral activity evaluation of some new adamantane derivatives. J. Med. Chem. 39, 3307-3318.

7. Kendal, A.B. \& Klenk, H.D. (1991) Method of determination of virus antigen in cell culture. Arch. Virol. 119, 265-273.

8. Prozorovski, V.B., Prozorovzki, M.P. \& Demchenko, V.M. (1978) An express-method for determination of mean effective dose and its errors. Farmakologiya i Toksikologiya 4, 497-502 (in Russian).

9. Bollum, F.J. (1968) Filterpaper disk technique for SN radioactive molecule. Methods Enzymol. 12, 169-173.

10. Mendzhul, M.I, Nesterova, N.V. \& Sukhanov, S.N. (1993) DNA-dependent DNA-polymerase from the cyanobacterium Plectonema boryanum: Isolation and partial purification. Mikrobiologichny Zhurnal 55, 46-51 (in Russian).

11. Furleng, F. (1986) A rapid assay for nucleotide kinases using $\mathrm{C}^{14}$ and $\mathrm{H}^{3}$ nucleotides. Ann. Biochem. 5, 515-522.

12. Sidelkovskays, F.P. (1970) Chemistry of the N-Vynilpyrrolodone and its Derivatives. Nauka. (Moscow) 162 (in Russian). 
13. Copolymers of $N$-vynilpyrrolidone with (met)acrylic acid as component for drugs. Brit. Patent 815225, 1959, Chem. Abstr. 1960, 53, P.22980.

14. Nazhimutdinov, Sh., Turayev, A.S. \& Usmanov, Kh.Ch. (1976) Monomer copolymerization leading to the formation of proton-donor-acceptor complexes following monomer functional group inter- actions. Dokl. Akad. Nauk S.S.S.R. 226, 1113-1116 (in Russian).

15. Challberg, M.D. \& Kelly, T.S. (1989) Animal virus DNA replication. Annu. Rev. Biochem. 59, 671717.

16. Novi, T.R. (1980) Nuclear war against herpesviruses. Med. Biol. 57, 5-7. 